\title{
KARAKTERISTIK GENETIK ENAM POPULASI IKAN NILEM (Osteochilus hasselti) DI JAWA BARAT
}

\author{
Mulyasari"), Dinar Tri Soelistyowati ${ }^{* *}$, Anang Hari Kristanto ${ }^{* * *}$, dan \\ Irin Iriana Kusmini") \\ ") Balai Riset Perikanan Budidaya Air Tawar \\ Jl. Raya Sempur No. 1, Bogor 16154 \\ E-mail: mulyasari_bogor@yahoo.co.id \\ *) Departemen Budidaya Perairan_FPIK, Institut Pertanian Bogor \\ Jl. Lingkar Akademik, Kampus IPB, Bogor 16680 \\ ***) Pusat Riset Perikanan Budidaya \\ Jl. Ragunan 20, Pasar Minggu, Jakarta Selatan 12540
}

(Naskah diterima: 10 Maret 2010; Disetujui publikasi: 25 Juni 2010)

\begin{abstract}
ABSTRAK
Penelitian karakteristik genetik populasi ikan nilem, Osteochilus hasselti di Jawa Barat dilakukan untuk mendapatkan data base sebagai langkah awal dalam melaksanakan program pemuliaan guna mempertahankan dan meningkatkan produksi dari ikan nilem di Jawa Barat. Tujuan penelitian ini adalah melakukan identifikasi genetik ikan nilem menggunakan metode RAPD dan menelusuri keragaman intra dan inter-populasi ikan nilem, Osteochilus hasselti di sentra budidaya yang terdapat di daerah Jawa Barat. Berdasarkan hasil penelitian, populasi Sumedang secara genetis memiliki keragaman paling tinggi dibandingkan dengan populasi lainnya serta alel spesifik yang tidak ditemukan pada populasi lain (1.100 bp). Sedangkan Sukabumi memiliki keragaman genetik dan jumlah alel yang paling rendah. Hubungan inter-populasi ikan nilem hijau di Jawa Barat tidak berbeda nyata di mana jarak genetik enam populasi ikan nilem tersebut berkisar antara 0,0153-0,1392.
\end{abstract}

KATA KUNCI: RAPD, ikan nilem, Osteochilus hasselti, Jawa Barat

ABSTRACT: Characteristic genetic of six population of nilem carp fish at West Java. By: Mulyasari, Dinar Tri Soelistyowati, Anang Hari Kristanto, and Irin Iriana Kusmini

Research on genetic variation was done to conduct breeding program as the effort to maintain and increase the production of nilem carp fish at West Java. The aim of this study was to identify nilem carp genetically and to estimate the variation of the intra and inter population of nilem carp fish from West Java using RAPD methods. The result showed that Sumedang population had the highest genetic variation and had specific allele that cannot be found at other population $(1,100 \mathrm{bp})$. But in contrast Sukabumi population had the lowest genetic variation and allele number. The interpopulation relationship among fish from West Java were not significantly different. Genetic distance among population were between 0.0153-0.1392.

KEYWORDS: RAPD, nilem fish, Osteochilus hasselti, West Java 


\section{PENDAHULUAN}

Ikan nilem, Osteochilus hasselti merupakan ikan Cyprinid yang banyak terdapat di daerah Jawa Barat. Ikan nilem ini sangat potensial untuk dikembangkan menjadi produk unggulan perikanan budidaya dari kawasan Priangan. Dari sisi ekonomi, kelestarian lingkungan, dan produksi, budidaya ikan ini menguntungkan. Nilai ekonomis ikan nilem meningkat setelah dijadikan produk olahan misalnya baby fish goreng, dendeng dan pindang, diasap dan dikalengkan (Rahardjo \& Marliani, 2007). Telur ikan nilem digemari masyarakat karena rasanya yang lezat dan mempunyai peluang sebagai komoditas ekspor (Winarlin et al., 2006; Subagja et al., 2006a). Dari aspek lingkungan ikan nilem berperan sebagai biocleaning agent karena sifatnya yang suka memakan detritus dan perifiton sehingga ikan ini bisa digunakan untuk membersihkan keramba jaring apung. Sedangkan dari segi budidayanya ikan nilem ini mudah dipelihara pada kondisi air yang berbeda-beda, memiliki sintasan dan reproduksi yang tinggi (Cholik et al., 2005) serta tahan terhadap penyakit (Subagja et al., 2006a). Berdasarkan keunggulan dan potensinya, Menteri Kelautan dan Perikanan mengukuhkan ikan ini sebagai salah satu komoditas Gerakan Mina Padi Rakyat atau GEMPAR pada tanggal 3 Mei 2006 (Subagja et al., 2006a,b).

Selama ini budidaya ikan nilem di karamba dan sawah masih sangat terbatas. Pemeliharaannya hanya bersifat sampingan dari hasil budidaya secara polikultur bersamasama dengan ikan mas, mujair atau gurame, sehingga produksinya masih relatif rendah. Oleh karena itu, untuk meningkatkan produksi ikan nilem yang berkelanjutan, hal ini perlu didukung oleh program pemuliaan atau perbaikan genetik stok yang unggul secara genetik. Perbaikan mutu genetik suatu jenis ikan berhubungan erat dengan tingkat keragaman genetik. Keragaman genetik penting keberadaannya dalam populasi dan terus-menerus dikelola dan harus diperluas agar selalu tersedia bahan untuk meningkatkan stok yang unggul. Informasi keragaman genetik, status genetik (gene pool) dan keunggulan sifat suatu populasi menjadi dasar kegiatan dalam melakukan program pemuliaan ikan. Dalam hal ini, seleksi dan persilangan merupakan dua metode yang dapat dilakukan dalam perbaikan mutu genetik untuk meningkatkan produktivitas suatu jenis ikan. Program seleksi dapat diterapkan jika keragaman genetik ikan nilem itu tinggi, dan apabila keragaman genetik rendah mungkin bisa dilakukan persilangan (hibridisasi). Selama ini keragaman genetik ikan nilem hanya terbatas pada informasi morfologinya sedangkan informasi genetik belum banyak dilakukan. Tujuan penelitian ini adalah melakukan identifikasi genetik ikan nilem menggunakan metode RAPD dan menelusuri keragaman intra dan inter-populasi ikan nilem Osteochilus hasselti di sentra budidaya yang terdapat di daerah Jawa Barat.

\section{METODOLOGI PENELITIAN}

\section{Pengadaan Ikan}

Ikan yang digunakan sebagai bahan penelitian ini terdiri atas jenis-jenis ikan nilem yang terdapat di daerah Jawa Barat yaitu: Bogor, Tasikmalaya, Kuningan, Sumedang, Cirata, dan Sukabumi (Gambar 1). Jumlah sampel yang digunakan untuk analisis morfomeristik masing-masing strain dan lokasi adalah 20 ekor sedangkan untuk analisis DNA sampel yang digunakan adalah 10 ekor. Pengambilan sampel dilakukan dengan bantuan pembudidaya setempat. Selanjutnya dari lokasi pengambilan, untuk analisis DNA sampel disimpan dalam larutan alkohol $70 \%$ sebelum dilakukan analisis lebih lanjut.

\section{Ekstraksi DNA}

Sampel ikan berupa sirip dorsal ditimbang sebanyak 0,5-1 mg dan dimasukkan ke dalam tabung Eppendorf 1,5 mL, kemudian dilisis dengan menambahkan larutan lisis ( $10 \mathrm{mM}$ tris $\mathrm{HCl} \mathrm{pH} \mathrm{7,5;} 125 \mathrm{mM} \mathrm{NaCl} ; 10 \mathrm{mM}$ EDTA pH 7,5; $0,5 \%$ SDS; dan $4 \mathrm{M}$ urea) sebanyak $500 \mu \mathrm{L}$ dan protein kinase sebanyak $15 \mu \mathrm{L}$. Setelah itu dikocok menggunakan alat vorteks dan diinkubasi pada suhu $37^{\circ} \mathrm{C}$ selama 24 jam atau sampai sirip hancur. Selanjutnya ditambahkan larutan Phenol: Chloroform: Isoamilalkohol (PCl) dengan perbandingan 25:24:1 sebanyak $1.000 \mu \mathrm{L}$ dan disentrifugasi pada kecepatan 10.000 rpm selama 10 menit. Supernatan lalu dipindahkan ke tabung baru dan ditambahkan etanol $90 \%$ sebanyak $1.000 \mu \mathrm{L}$ dan $\mathrm{Na}$ asetat sebanyak $10 \mu \mathrm{L}$ lalu disentrifugasi pada kecepatan $10.000 \mathrm{rpm}$ selama 10 menit. Supernatan dibuang dan pellet dikering anginkan sampai etanol menguap. DNA dilarutkan dengan menambahkan rehydration 


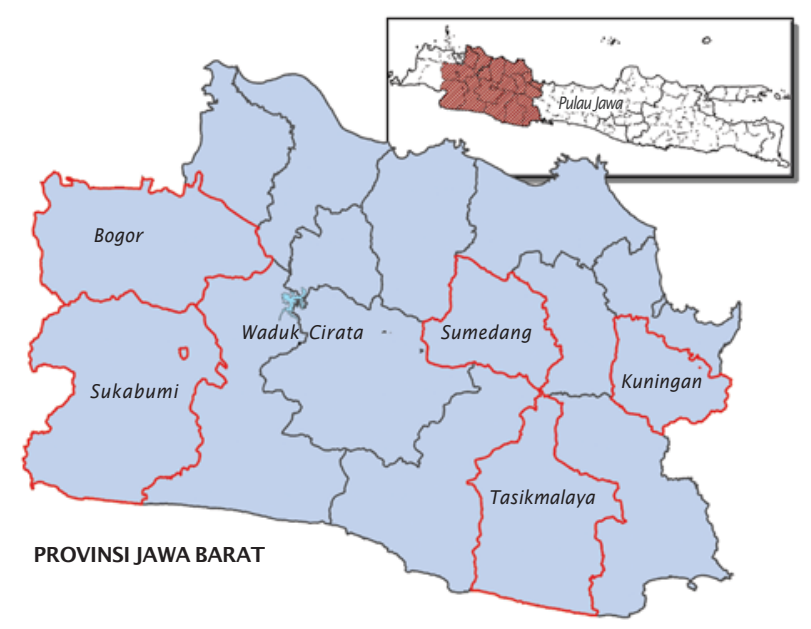

Gambar 1. Lokasi pengambilan sampel

Figure 1. Sampling location

solution sebanyak $100 \mu \mathrm{L}$ dan disimpan pada suhu $4^{\circ} \mathrm{C}$ selama semalam atau pada suhu $65^{\circ} \mathrm{C}$ selama 1 jam. Jika DNA belum akan digunakan dalam jangka waktu lama maka disimpan pada suhu $-20^{\circ} \mathrm{C}$.

\section{Amplifikasi DNA dengan Teknik PCR}

Sebelum amplifikasi DNA, dilakukan seleksi primer untuk mendapatkan jenis primer yang sesuai. Amplifikasi DNA dilakukan menggunakan metode PCR dengan komposisi bahan sebagai berikut: $2 \mu \mathrm{L}$ DNA genom hasil ekstraksi, $2 \mu \mathrm{L}$ primer, 8,5 $\mu \mathrm{L}$ distilled water dicampur dengan 12,5 $\mu \mathrm{L}$ master mix PCR Fermentas (komposisi: PCR buffer, enzim Taq polymerase, $\mathrm{MgCl}_{2}$ dan dNTP mix) sehingga total volume menjadi $25 \mu \mathrm{L}$. Campuran tersebut kemudian dimasukkan ke dalam mesin PCR yang sudah diprogram. Secara umum proses PCR terdiri atas tiga tahap yaitu denaturasi (penguraian utas ganda DNA), penempelan primer (annealing), dan pemanjangan utas DNA (elongasi). Predenaturasi dilakukan pada suhu $94^{\circ} \mathrm{C}$ selama 2 menit untuk memastikan kesempurnaan denaturasi, sedangkan denaturasi dilakukan pada suhu $94^{\circ} \mathrm{C}$ selama 1 menit, annealing pada suhu $36^{\circ} \mathrm{C}$ selama 1 menit, dan elongasi pada suhu $72^{\circ} \mathrm{C}$ selama 2 menit. Elongasi akhir dilakukan pada suhu $72^{\circ} \mathrm{C}$ selama 7 menit untuk meyakinkan proses elongasi berjalan sempurna, proses PCR ini berjalan sebanyak 35 siklus. Untuk mengetahui keberhasilan amplifikasi primer yang dicobakan, campuran
$9 \mu \mathrm{L}$ hasil PCR dengan $2 \mu \mathrm{L}$ loading dye dielektroforesis pada gel agarose $2 \%(\mathrm{w} / \mathrm{v})$ dalam larutan TBE dan tegangan 100 Volt selama 30 menit. Gel direndam dalam larutan etidium bromida agar pita DNA dapat terlihat pada cahaya ultra violet untuk keperluan dokumentasi menggunakan kamera. Gene Ruler 100bp DNA ladder digunakan sebagai standar untuk menentukan ukuran fragmen hasil amplifikasi.

\section{Analisis Data}

Parameter yang diukur dalam penelitian ini adalah keragaman genetik dan morfologi serta filogenetik dari ikan nilem yang ada di daerah Jawa Barat. Untuk mengukur parameter tersebut di atas, ada beberapa karakter yang dianalisis sebagai berikut:

a. Derajat polimorfisme

$$
\text { P } 0.95=\frac{\text { Jumlah lokus polimorfik }}{\text { Jumlah lokus total }} \times 100 \%
$$

b. Heterozigositas populasi ikan nilem

$$
h=1-\sum_{i=1}^{n} \mathrm{xi}^{2}
$$

di mana:

$$
h=\text { Heterozigositas }
$$

$n$ = Jumlah sampel

$\mathrm{Xi}^{2}=$ Frekuensi alel $\mathrm{ke}-\mathrm{i}$ 
c. Jarak genetik

$$
D=-\ln \frac{J_{a b}}{\left(J_{a} \times J_{b}\right)^{0.5}}
$$

di mana:

$\mathrm{D}=$ Jarak genetik

$\mathrm{J}_{\mathrm{ab}} \quad=$ Frekwensi haplotipe pada lokus populasi yang sama

$\mathrm{J}_{\mathrm{a}}$ dan $\mathrm{J}_{\mathrm{b}}=$ Frekwensi haplotipe pada populasi $\mathrm{A}$ dan B

Untuk menentukan jarak genetik dan pembuatan dendrogram dilakukan dengan metode Unweight Pair Group Methods Arithmetic (UPGMA), data biner dianalisis dengan menggunakan program komputer Tools For Population Genetic Analysis (TFPGA) (Miller, 1997).

\section{HASIL DAN BAHASAN}

\section{Hasil}

Dari 20 primer yang dicoba ada 4 primer yang menghasilkan fragmen-fragmen dari DNA nilem yang di uji yaitu OPA-03, OPA-11, OPA13, dan OPA-18. Namun hanya 1 primer menunjukkan hasil PCR yang paling baik yaitu OPA-11. Primer OPA-11 mempunyai fragmen yang dapat digunakan sebagai pembeda di antara populasi ikan nilem hijau yang diuji. Gambar hasil RAPD disajikan dalam Gambar 2. Beberapa fragmen RAPD yang didapatkan mengindikasikan fragmen spesifik populasi yakni fragmen yang hanya didapatkan pada populasi tertentu. Misalnya fragmen $1.100 \mathrm{bp}$ yang hanya didapatkan pada populasi Sumedang dan fragmen 400 bp pada populasi Bogor. Fragmen 3.100 bp hanya dimiliki oleh populasi Sumedang dan Kuningan, fragmen 1.700 bp hanya ada pada populasi Sumedang dan Tasikmalaya, fragmen 225 bp pada populasi Bogor dan Sukabumi, sedangkan fragmen 1.300 dan 500 bp pada populasi Bogor dan Kuningan. Fragmen 2.900 dan 1.500 bp hanya dimiliki oleh populasi Tasikmalaya, Sumedang, dan Bogor, sedangkan fragmen $1.600 \mathrm{bp}$ hanya ada pada populasi Tasikmalaya, Sumedang, dan Kuningan. Fragmen 750 bp didapatkan pada semua populasi ikan nilem di Jawa Barat kecuali Sukabumi.

Keragaman genetik yang ditentukan oleh nilai rata-rata heterozigositas dan persentase polimorfisme ikan nilem hijau yang dianalisis disajikan dalam Tabel 1. Heterozigositas dari enam populasi ikan nilem hijau di Jawa Barat memiliki nilai yang hampir sama berkisar antara $0,1054-0,2138$. Nilai heterozigositas tertinggi terlihat pada populasi dari Sumedang $(0,2138)$ dan nilai terendah adalah ikan yang berasal dari Sukabumi $(0,1054)$. Sedangkan persentase polimorfisme dari enam populasi ikan nilem hijau tersebut berkisar antara 40\%-68\%. Persentase polimorfisme tertinggi berasal dari daerah Sumedang yaitu $68 \%$, sedangkan persentase polimorfisme terendah berasal dari Cirata yaitu $40 \%$.

Secara statistik dengan menggunakan uji perbandingan berpasangan Fst menunjukkan bahwa tidak terdapat perbedaan genetik yang nyata antara populasi ikan yang diuji $(\mathrm{P}>0,05)$

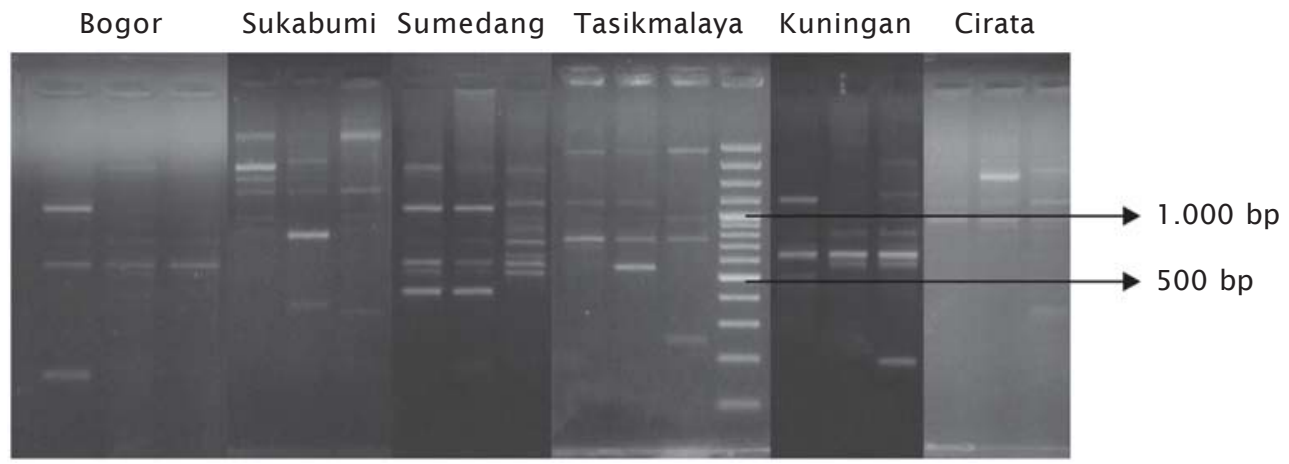

Gambar 2. Pola fragmen RAPD ikan nilem dari enam populasi di Jawa Barat yang diamplifikasi menggunakan primer OPA-1 1

Figure 2. RAPD fragment pattern of nilem carp from six population at West Java that amplified used OPA-11 primer 
Tabel 1. Heterozigositas dan persentase polimorfisme enam populasi ikan nilem di Jawa Barat hasil RAPD menggunakan primer OPA-1 1

Table 1. Heterozigosity and polymorphism percentage of nilem carp from six population at West Java used OPA-1 1 primer

\begin{tabular}{lcccccc}
\hline & SKB & BGR & CRT & SMD & TSM & KNG \\
\hline $\begin{array}{l}\text { Heterozigositas } \\
\begin{array}{l}\text { Heterozigosity } \\
\text { Polimorfisme }\end{array}\end{array}$ & 0.1054 & 0.1674 & 0.1095 & 0.2138 & 0.1698 & 0.1877 \\
\begin{tabular}{l} 
Polymophism (\%) \\
\hline
\end{tabular} & 44 & 64 & 40 & 68 & 64 & 60 \\
\hline
\end{tabular}

Keterangan (Remark):

$\mathrm{SKB}=$ Sukabumi; BGR = Bogor; SMD = Sumedang

$\mathrm{CRT}=$ Cirata; $\mathrm{TSM}=$ Tasikmalaya; $\mathrm{KNG}=$ Kuningan

kecuali antara populasi Sumedang dengan Sukabumi, Bogor dan Cirata serta antara populasi Tasikmalaya dengan Sukabumi $(P<0,05)$ seperti terlihat pada Tabel 2.

Jarak genetik (D) yang dihitung menurut Nei (1978) dalam Miller (1997), secara komputasi dengan program TFPGA berdasarkan fragmen RAPD dari primer OPA-11 antara koleksi ikan nilem hijau tertera pada Tabel 3. Berdasarkan perhitungan jarak genetik dari 6 populasi ikan nilem hijau, diperoleh nilai jarak genetik terdekat adalah antara populasi dari Cirata dengan populasi dari Kuningan yaitu sebesar 0,0153; kemudian antara populasi Bogor dengan Kuningan yaitu 0,0175 dan antara populasi Bogor dengan Cirata yaitu
0,0233 . Berikutnya adalah jarak genetik antara populasi Kuningan dengan populasi Sumedang yaitu 0,0251, populasi Kuningan dengan populasi Tasikmalaya $(0,0317)$ dan antara populasi Bogor dengan populasi Tasikmalaya $(0,0337)$ serta populasi Cirata dengan populasi Tasikmalaya $(0,0525)$. Selanjutnya adalah jarak genetik antara populasi Sumedang dengan populasi Tasikmalaya $(0,0528)$, populasi Bogor dengan Sumedang $(0,0618)$, populasi Bogor dengan Sukabumi $(0,0770)$, dan antara populasi Cirata dengan Sukabumi $(0,0773)$. Kemudian antara Sumedang dengan Cirata $(0,0815)$ dan antara Sumedang dengan Sukabumi yaitu sebesar 0,1046 . Sedangkan jarak genetik terjauh adalah antara Sukabumi dengan Tasikmalaya $(0,1392)$.

Tabel 2. Uji perbandingan berpasangan Fst enam populasi ikan nilem di Jawa Barat

Table 2. Pairwise comparison test Fst of nilem carp from six population at West Java

\begin{tabular}{lclllll}
\hline & SKB & BGR & CRT & SMD & TSM & KNG \\
\hline SKB & $* * * * * *$ & & & & & \\
BGR & 0.4393 & $* * * * *$ & & & & \\
CRT & 0.1789 & 0.967 & $* * * * *$ & & & \\
SMD & $0.0182 *$ & $0.0109 *$ & $0.0007 *$ & $* * * * *$ & & \\
TSM & $0.0013^{*}$ & 0.9074 & 0.4646 & 0.3452 & $* * * * *$ & \\
KNG & 0.215 & 0.7596 & 0.7862 & 0.9937 & 0.7336 & $* * * * *$ \\
\hline
\end{tabular}

Keterangan (Remark):

$\mathrm{SKB}=$ Sukabumi; BGR = Bogor; SMD = Sumedang

$\mathrm{CRT}=$ Cirata; TSM = Tasikmalaya; $\mathrm{KNG}=$ Kuningan

* Beda nyata (Significantly difference) 
Tabel 3. Matriks jarak genetik inter-populasi ikan nilem di Jawa Barat Table 3. Genetic distance matrix of nilem carp inter-population at West Java

\begin{tabular}{|c|c|c|c|c|c|c|}
\hline & SKB & BGR & CRT & SMD & TSM & KNG \\
\hline SKB & $* * * * * *$ & & & & & \\
\hline BGR & 0,0770 & $* * * * * *$ & & & & \\
\hline CRT & 0,0773 & 0,0233 & $* * * * *$ & & & \\
\hline SMD & 0,1046 & 0,0618 & 0,0815 & $* * * * *$ & & \\
\hline TSM & 0,1392 & 0,0337 & 0,0525 & 0,0528 & $* * * * *$ & \\
\hline KNG & 0,0875 & 0,0175 & 0,0153 & 0,0251 & 0,0317 & $* * * * *$ \\
\hline
\end{tabular}

Keterangan (Remark):

$\mathrm{SKB}=$ Sukabumi; $\mathrm{BGR}=$ Bogor; SMD = Sumedang

CRT = Cirata; $T S M=$ Tasikmalaya; $K N G=$ Kuningan

Dendrogram yang dibentuk berdasarkan jarak genetik tersebut dengan menggunakan program Unweighted Pair Group Arithmatic Average (UPGMA) memperlihatkan hubungan terdekat adalah antara populasi Cirata dengan Kuningan, Bogor dan Tasikmalaya sedangkan yang terjauh adalah antara keempat populasi tersebut dengan Sukabumi (Gambar 3).

\section{Bahasan}

Keragaman genetik ikan nilem hijau yang dianalisis menggunakan RAPD ditentukan oleh nilai rata-rata heterozigositas dan persentase polimorfisme dari ikan nilem tersebut. Nilai polimorfisme ikan nilem hijau ini cukup tinggi yaitu sekitar $40 \%-68 \%$, namun nilai rata-rata heterozigositasnya termasuk rendah yaitu berkisar antara 0,1054-0,2138. Hal ini dapat disebabkan oleh antara lain ikan nilem hijau dibudidaya dalam kondisi lingkungan yang relatif stabil. Menurut Sugama et al. (1996), pada lingkungan yang stabil akan lebih sedikit ditemukan variasi alel daripada kondisi lingkungan yang labil, karena laju mutasi dan
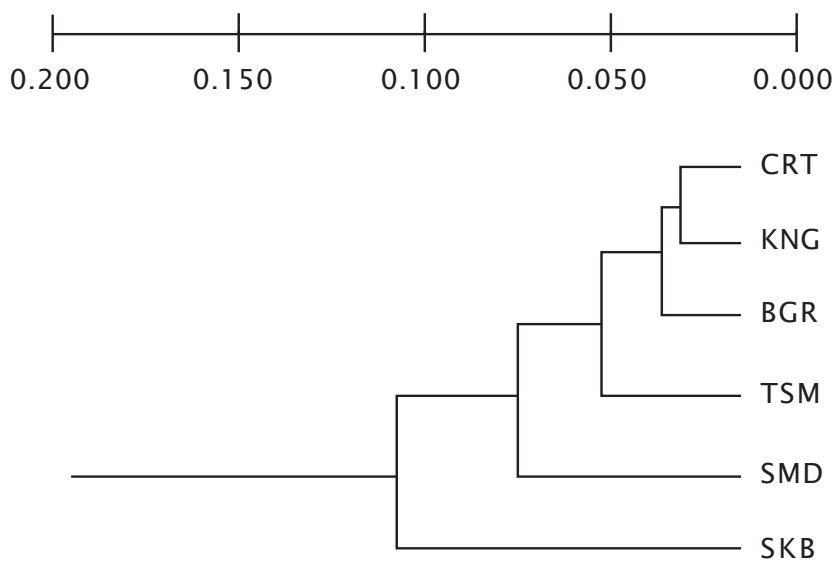

Keterangan (Remark):

SKB = Sukabumi; BGR = Bogor; CRT = Cirata

SMD = Sumedang; TSM = Tasikmalaya; KNG = Kuningan

Gambar3. Dendrogram hubungan kekerabatan enam populasi ikan nilem yang terdapat di Jawa Barat

Figure 3. Dendrogram of genetic distance between six population of nilem carp from West Java 
seleksi lingkungan relatif rendah. Selain itu, pengelolaan sistem rekrutmen atau peremajaan ikan nilem hijau tidak terarah sehingga dapat menyebabkan terjadinya seleksi tanpa sengaja yang mempengaruhi gene pool ikan tersebut. Berdasarkan data sekunder selama penelitian, proses rekrutmen yang dilakukan pada populasi Bogor dan Tasikmalaya menggunakan induk dari satu populasi saja dan jumlah pasangan induk yang digunakan pun terbatas. Menurut Tave (1995), perkawinan yang dilakukan tanpa memperhatikan silsilah tetuanya memiliki peluang untuk terjadinya perkawinan sekerabat, di mana perkawinan tersebut akan meningkatkan nilai inbreeding yang ditandai dengan penurunan heterozigositas dan variasi alelik. Perbandingan induk jantan dan betina yang tidak sama, sedikitnya jumlah pasang induk yang digunakan dalam pemijahan dan perbedaan jumlah induk yang digunakan dari generasi ke generasi dapat meningkatkan terjadinya Inbreeding (Soewardi, 2007). Inbreeding akan mengurangi heterozigositas dari suatu populasi ikan dan penurunan variasi gen yang berakibat pada hilangnya alel pengontrol pertumbuhan, ketahanan terhadap penyakit yang berakibat fatal bagi keturunan berikutnya dan terjadinya abnormalitas (Tave, 1995).

Berdasarkan hasil keragaman antar populasi dengan melakukan uji perbandingan berpasangan Fst (selang kepercayaan 95\%), hasil tersebut memperlihatkan bahwa antara populasi ikan nilem yang diuji umumnya tidak berbeda nyata secara genetik $(P>0,05)$ kecuali antara populasi Sumedang dengan Sukabumi, Bogor, dan Cirata serta antara populasi Tasikmalaya dengan Sukabumi $(\mathrm{P}<0,05)$. Beda nyata antar populasi-populasi tersebut mengindikasikan bahwa induk populasi Sumedang berasal dari induk yang memiliki keragaman genetik yang berbeda dengan populasi Bogor dan Cirata, demikian pula populasi Tasikmalaya dengan Sukabumi. Sedangkan populasi yang tidak berbeda nyata, mungkin disebabkan oleh banyaknya kesamaan genetik antar populasi-populasi tersebut. Jarak genetik rata-rata ikan nilem dari enam lokasi di Jawa Barat adalah 0,07725, lebih kecil dari jarak genetik ikan pada sub spesies yang sama seperti ikan batak (Tor sorro) (Asih et al., 2008) dan butini (Glossogobius matanensis) (Mamangkey et al., 2007). Hal ini menunjukkan adanya kedekatan hubungan kekerabatan antara populasi ikan nilem yang ada di Jawa Barat. Populasi ikan nilem hijau yang berasal dari Kuningan, Cirata, Bogor, dan Tasikmalaya memiliki hubungan kekerabatan yang lebih dekat bila dibandingkan dengan Sumedang dan Sukabumi. Berdasarkan hasil wawancara dengan pembudidaya, diketahui bahwa ikan nilem hijau dari daerah Bogor dan Kuningan berasal dari sumber induk yang sama yaitu daerah Tasikmalaya, sedangkan ikan yang dipelihara di daerah Cirata juga merupakan ikan yang berasal dari daerah Tasikmalaya, sehingga sangat jelas jika ikan dari keempat lokasi tersebut memiliki jarak genetik yang dekat. Ikan nilem asal Tasikmalaya dan Kuningan memiliki jarak genetik yang dekat dengan populasi Sumedang dibanding dengan populasi lain, diduga hal ini terjadi karena sumber induk untuk daerah Tasikmalaya berasal dari Sumedang. Demikian pula dengan ikan nilem yang berasal dari Kuningan, selain mengambil induk dari Tasikmalaya ada kemungkinan budidaya ikan nilem di Kuningan juga menggunakan induk yang berasal dari daerah Sumedang. Hal ini dapat dilihat dari pola fragmen ketiga populasi ini yang lebih banyak menunjukkan kesamaan bila dibandingkan dengan populasi lain. Sukabumi memiliki jarak genetik terjauh dengan populasi lain. Bila dilihat dari pola fragmennya, Sukabumi tidak memiliki fragmen 750 bp yang dimiliki oleh populasi lainnya sehingga menghasilkan jarak genetik yang jauh dengan populasi lain. Hal ini dapat terjadi kemungkinan karena induk yang digunakan untuk budidaya jumlahnya sangat terbatas selain itu, antara populasi Sukabumi dengan populasi lain tidak terjadi pertukaran gen, sehingga peluang terjadinya inbreeding sangat besar yang menyebabkan peluang hilangnya alel-alel tertentu juga besar dan pada akhirnya akan memiliki keragaman alel yang berbeda dengan kelompok lainnya walaupun secara garis keturunan masih satu kerabat (Nugroho et al., 2006).

\section{KESIMPULAN}

Hasil analisis RAPD menunjukkan bahwa nilai polimorfisme ikan nilem hijau adalah 40\%-68\%, dan nilai rata-rata heterozigositasnya berkisar antara 0,1054-0,2138. Hubungan inter-populasi ikan nilem hijau di Jawa Barat tidak berbeda nyata. Populasi Sumedang secara genetis memiliki keragaman paling tinggi dibandingkan dengan populasi lainnya 
serta alel spesifik yang tidak ditemukan pada populasi lain (1.100 bp). Sedangkan Sukabumi memiliki keragaman genetik dan jumlah alel yang paling rendah. Jarak genetik enam populasi ikan nilem hijau di Jawa Barat berkisar antara 0,0153-0,1392.

\section{DAFTAR ACUAN}

Asih, S., Nugroho, E., Kristanto, A.H., \& Mulyasari. 2008. Penentuan variasi genetik ikan batak (Tor sorro) dari Sumatera Utara dan Jawa Barat dengan metode analisis Randomly Amplified Polymorphism DNA (RAPD). J. Ris. Akuakultur, 3(1): 91-97.

Cholik, F., Jagatraya, A.G, Poernomo, R.P., \& Jauzi, A. 2005. Akuakultur: Tumpuan Harapan Masa Depan Bangsa. Masyarakat Perikanan Nusantara dan Taman Akuarium Air TawarTMII, Jakarta, $415 \mathrm{hlm}$.

Mamangkey, J.J., Sulistiono, Sjafei, D.S., Soedharma, D., Sukimin, S., \& Nugroho, E. 2007. Keragaman genetik ikan endemik butini (Glossogobius matanensis) berdasarkan penanda Randomly Amplified Polymorphism DNA (RAPD) di Danau Towuti Sulawesi Selatan. J. Ris. Akuakultur, 2(3): 389-397.

Nugroho, E., Subagja, J., Asih, S., \& Kurniasih, T. 2006. Evaluasi keragaman genetik ikan kancra dengan menggunakan marker mtDNA D-loop dan Randomly Amplified Polymorphism DNA (RAPD). J. Ris. Akuakultur, 1(2): $211-217$.

Rahardjo, A.A. \& Marliani, L. 2007. Nilem: Diolah Naik Derajat. Trubus. http://www.trubus. com [21 Maret 2008].
Soewardi, K. 2007. Pengelolaan keragaman genetik sumberdaya perikanan dan kelautan. Departemen Manajemen Sumberdaya Perairan, Fakultas Perikanan dan Ilmu Kelautan, Institut Pertanian Bogor, Bogor, $153 \mathrm{hlm}$.

Subagja, J., Gustiano, R., \& Djajasewaka, H. 2006a. Penentuan dosis hormon steroid dan teknik pemberian untuk feminisasi ikan nilem (Osteochilus hasselti). Laporan Hasil Riset Balai Riset Perikanan Budidaya Air Tawar Tahun Anggaran 2006. Balai Riset Perikanan Budidaya Air Tawar Bogor, Badan Riset Kelautan dan Perikanan, hlm. 300-312.

Subagja, J., Gustiano, R., \& Winarlin, L. 2006b. Pelestarian ikan nilem (Osteochilus hasselti CV) melalui teknologi perbenihannya. Prosiding Lokakarya Nasional Pengelolaan dan Perlindungan Sumberdaya Genetik di Indonesia, Bogor, 20 Desember 2006, hlm. 279-286.

Sugama, K., Haryanti, \& Cholik, F. 1996. Biochemical genetics of tiger shrimp Penaeus monodon : description electrophoresis detectable loci. Indonesian Fish Res. J. $11(1): 19-28$.

Tave, D. 1995. Selective Breeding Programme for Medium-Sized Fish Farms. FAO FishTechnical Paper. No. 352. Rome, Italy, 122 pp.

Winarlin, L., Setiadi, E., Widiyati, A. \& Djajasewaka, H. 2006. Pengaruh tingkat kedalaman air terhadap perkembangan pakan alami untuk pertumbuhan benih ikan nilem (Osteochilus hasselti CV). Laporan Hasil Riset Balai Riset Perikanan Budidaya Air Tawar Tahun Anggaran 2006. Balai Riset Perikanan Budidaya Air Tawar Bogor, Badan Riset Kelautan dan Perikanan, hlm. 313-332. 